\title{
Effect of Harvesting Stages and Biochemical Factors on Pod Shattering in Soybean, Glycine max (L.) Merrill.
}

\author{
Ashvini P. Gaikwad* and R.W. Bharud \\ Department of Agriculture Botany, Discipline-Seed Science \& Technology, MPKV, Rahuri, \\ Dist. Ahmednagar-413722, India \\ *Corresponding author
}

\section{A B S T R A C T}

\section{Keywords}

Cellulase,

Polygalactouranase,

Lignin, Harvesting stages

and pod wall

Article Info

Accepted:

10 October 2018

Available Online:

10 November 2018
Specific activity of two hydrolytic enzymes viz., cellulase and polygalactouranase was assayed in the shattering and non-shattering zones of pod wall and lignin content in pod wall of soybean varieties at four harvesting stages viz., at physiological maturity, 5 DAPM, 10 DAPM and 15 DAPM. The cellulase enzyme activities was lowest at non-shattering zone of pod wall of the susceptible varieties as compare to the resistant varieties but highest at shattering zone of pod wall of the susceptible varieties indicating its role in pod shattering. Polygalactouranase enzyme activity was highest at shattering zone of pod wall of the resistant varieties than the susceptible varieties, protecting it from shattering. The activity of cellulase and polygalactouranase enzyme goes on increasing after physiological maturity onwards in both susceptible as well as in resistant varieties. The lignin content in pod wall of soybean varieties also goes on increasing after physiological maturity onwards in both varieties (Susceptible and resistant) but highest lignin content in pod wall of susceptible varieties.

\section{Introduction}

Shattering occurs due to loss of adhesion between highly active living cells. It is a result of highly coordinated sequence of biochemical events, which leads to cell wall breakdown in one or two rows of cell on either side of the shattering zone.

The time occurs in which the induction and completion of separation takes place can usually be divided into 'lag' and 'separation' phase. During the lag phase, there is either no perceptible fall in the break strength or shallow decline. During the separation phase, the shattering layer is rapidly weakened in the adjacent tissue and ultimately fractures the cell wall. The cell wall degrading hydrolytic enzymes play an important role in the cell wall separation. Shattering takes place following dehydration of the pod wall and separation of the cells in a dehiscence zone which is situated in sutures between the lignified pod wall edge and a replum containing vascular tissue.

Pod-shattering in soybean crop is of widespread occurrence, but the process has largely failed to stimulate detailed examination at the biochemical level. As a result, little information is available on this 
phenomenon and this situation has retarded the development of effective manipulative strategies.

\section{Materials and Methods}

\section{Lignin content in pod wall (per cent)}

The lignin content of pod wall was determined as per titration method given by (Hussain et al., 2002). $0.1 \mathrm{~g}$ of soybean pod wall in powder form were dispersed in $6 \mathrm{ml}$ distilled water and ground to fine paste by using mortar and pestle. The disintegrated sample was transferred to $250 \mathrm{ml}$ conical flask and distilled water was added to make the total volume to $120 \mathrm{ml} .15 \mathrm{ml}$ of potassium permanganate solution and $15 \mathrm{ml}$ of sulphuric acid solution were mixed together and added immediately to the disintegrated pod wall sample. Thus, the total volume was made to $150 \mathrm{ml}$ with distilled water. The reaction was allowed to proceed at $25^{\circ} \mathrm{C}$ temperature for exactly 10 minutes in temperature bath maintained with $25^{\circ} \mathrm{C}$ temperature. Then $3 \mathrm{ml}$ of potassium iodide solution was added and the free iodine was titrated with standard sodium thiosulphate solution using starch as an indicator. A blank titration was made using the same volume of water and reagents.

The Kappa Number was then calculated from the following equation:

$\operatorname{Kappa} \operatorname{Number}(\mathrm{k})=\frac{p \times f}{W}$

Where,

$\mathrm{p}=$ Millilitre of $0.1 \mathrm{~N}$ potassium permanganate consumed by the experimental soybean pod wall sample.

$\mathrm{W}=$ Weight in gram of moisture free pod wall sample. $\mathrm{f}=$ Factor for correction to 50 per cent permanganate consumption, which has been shown in table 1.

\section{Enzyme activity}

The pods were collected in the morning hours preferably between 8 to 9 am at indicated stages of harvesting. The pods were detached from plants and brought to the laboratory in chilled condition. The pod samples were partitioned into two parts viz., shattering zone (periphery portion) and non-shattering zone (central portion) of pod wall as shown in Figure 1. Enzyme activities in shattering and non-shattering zone of soybean pod wall were assessed after each harvesting.

\section{Polygalactouranase}

The combined modified procedure described by Berger and Reid (1979) and Favaron et al., (1994) was used for polygalactouranase (PG) assay.

\section{Reagents}

Tris $\mathrm{HCl} \quad 0.017 \quad \mathrm{M}$ containing 2mercaptoethanol $5 \mathrm{mM}$, pH 10

Extraction buffer: $\mathrm{NaCl} 1.7 \mathrm{M}, 50 \mathrm{ml}$ sodium citrate $(0.1 \mathrm{M})$ and EDTA $15 \mathrm{mM}, \mathrm{pH} 5.5$

Alkaline copper reagent

Arseno molybdate

Sodium acetate buffer $\mathrm{pH} 5.0$

Sodium polypectate

Standard D-galacturnoic acid

\section{Enzyme extraction}

Homogenized $10 \mathrm{~g}$ of each sample from shattering and non-shattering zone of pod wall in $13 \mathrm{ml}$ of Tris $\mathrm{HCl}$ buffer.

Centrifuged at $15000 \mathrm{rpm}$ for $15 \mathrm{~min}$. 
Incubated the pellet for $60 \mathrm{~min}$. in about $5 \mathrm{ml}$ of extraction buffer.

Centrifuged at $15000 \mathrm{rpm}$ for $30 \mathrm{~min}$. Used the supernatant for assay.

\section{Enzyme assay}

The incubation mixture consisted of $1.0 \mathrm{ml}$ of $50 \mathrm{mM}$ sodium acetate buffer ( $\mathrm{pH} 5.0), 0.5 \mathrm{ml}$ enzyme extract, $0.5 \mathrm{ml}$ sodium polypectate ( 0.5 per cent $\mathrm{w} / \mathrm{v}$ ) containing $0.1 \mathrm{mg}$ per $\mathrm{ml}$ of bovine serum albumin. The reaction mixture was incubated for $1 \mathrm{hr}$ at $37^{\circ} \mathrm{C}$. A reaction mixture to which the active enzyme was added at the end of incubation period served as a blank. The reaction was terminated by adding $1.0 \mathrm{ml}$ of alkaline copper reagent, mixed thoroughly and the mixture was boiled for exactly $20 \mathrm{~min}$ and cooled in running tap water. Then $1.0 \mathrm{ml}$ arseno molybdate was added with instant mixing for the colour development. The volume was made up to 25 $\mathrm{ml}$ and the absorbance was measured at 575 $\mathrm{nm}$. D-galacturnoic acid was used as standard. The activity of PG was expressed as micromoles D-galacturnoic acid released per hour per mg of protein.

\section{Cellulase}

The cellulase activity was assayed according to the procedure described by Sadashivam and Manickam (1992).

\section{Reagents}

Sodium citrate buffer, $0.1 \mathrm{M}, \mathrm{pH} 6.0$

Carboxymethyl cellulose 1 per cent

Dinitrosalicylic acid (DNS)

\section{Enzyme extraction}

Homogenized $0.5 \mathrm{~g}$ each sample from shattering and non-shattering zone of pod wall in $0.1 \mathrm{M}$ sodium citrate buffer, $\mathrm{pH} 6.0$
Centrifuged at $10000 \mathrm{rpm}$ for $20 \mathrm{~min}$.

Supernatant was collected.

It was used as the enzyme source.

\section{Enzyme assay}

The reaction mixture consisting of $0.5 \mathrm{ml}$ sodium citrate buffer, $0.5 \mathrm{ml}$ carboxymethyl cellulose and $0.5 \mathrm{ml}$ enzyme extract was incubated at $55^{\circ} \mathrm{C}$ for $15 \mathrm{~min}$ in a water bath. Immediately after removing the incubated mixture from the water bath, $0.5 \mathrm{ml}$ of dinitrosalicylic acid (DNS) reagent was added. However, $0.5 \mathrm{ml}$ of DNS reagent was added to the blank before incubation. The mixture was kept in a boiling water bath for $5 \mathrm{~min}$, cooled to room temperature and the volume was made up to $5.0 \mathrm{ml}$. The absorbance was measured at $540 \mathrm{~nm}$ against the blank. A standard graph of glucose was used for measuring cellulase activity. The enzyme activity was expressed as micromoles of Dglucose released per $15 \mathrm{~min}$ per $\mathrm{mg}$ of protein.

\section{Results and Discussion}

\section{Lignin content in pod wall}

According to the physical characteristics, lignin is hard, which increases the hardness of the cell wall. Commonly, the cell wall of plants with a supporting function and mechanical action always contains high lignin content. The lignin content is about 27-32 per cent in woody plants and about 14-25 per cent in herbaceous plants (Chen et al., 1996).

The statistically analyzed results showed that the variety, harvesting stages and interaction effect significantly influenced the lignin content in pod wall of soybean varieties (Fig. 2).

Lignin content of pod wall was highest in pod shattering susceptible varieties viz., KDS-837 and KDS-798 as compared to pod shattering 
tolerant JS-335 and resistant DS-9712 varieties. Lignin deposition in pod wall was observed to be increased after PM (H1). Rate of lignin deposition in pod wall was slow when pod wall had high moisture content and it went on increasing along with decrease in pod wall moisture content. Increased lignification showed to be increase in pod shattering. Similar, results were also reported by Buscaglia et al., (1994), Moore and Jung (2001), Roberts et al., (2002) and Romkaew et al., (2008). The lignification process is the deposition process of lignin in plant tissues. In the cell wall lignification process, lignin penetrates into the cell walls and fills in their framework, which increases the hardness of the cell wall, enhancing the mechanical and the compressive strengths, promoting the formation of mechanical tissues and consolidating the plant body and water conduction.

\section{Enzyme activity}

Polygalactouranase activity in nonshattering and shattering zone of pod wall ( $\mu$ g of D-galacturnoic acid produced.mg ${ }^{-1}$ protein.min ${ }^{-1}$ )

The varietal variation in polygalactouranase activity in non-shattering zone of pod wall ranged from $0.29 \mu \mathrm{g}$ of $\mathrm{D}$-galacturnoic acid produced. $\mathrm{mg}^{-1}$ protein. $\mathrm{min}^{-1}$ in variety JS-335 (V3) to $0.58 \mu \mathrm{g}$ of $\mathrm{D}$ - galacturnoic acid produced. $\mathrm{mg}^{-1}$ protein. $\mathrm{min}^{-1}$ in variety KDS837 (V1). It was noticed that the pod shattering resistant DS-9712 (V4) and tolerant JS-335 (V3) varieties had less polygalactouranase activity in central portion as compared to pod shattering susceptible varieties viz., KDS-837 (V1) and KDS-798 (V2) which showed higher polygalactouranase activity in central portion (Fig. 3).

The varietal variation in polygalactouranase activity in shattering zone of pod wall ranged from $0.27 \mu \mathrm{g}$ of $\mathrm{D}$-galacturnoic acid produced. $\mathrm{mg}^{-1}$ protein. $\mathrm{min}^{-1}$ in variety KDS798 (V2) to $0.41 \mu \mathrm{g}$ of D- galacturnoic acid produced. $\mathrm{mg}^{-1}$ protein. $\mathrm{min}^{-1}$ in variety DS9712 (V4). It was noticed that the pod shattering resistant DS-9712 (V4) and tolerant JS-335 (V3) varieties had higher polygalactouranase activities in peripheral portion i.e. in shattering zone as compared to pod shattering susceptible varieties viz., KDS837 (V1) and KDS-798 (V2) which showed less polygalactouranase activity in shattering zone. It means increased activity of polygalactouranase in shattering zone of resistant variety may help in protecting it from shattering by softening the tissues in dehiscence zones of pod wall (Fig. 4).

The variation in polygalactouranase activity in non-shattering zone of pod wall due to harvesting stages ranged from $0.36 \mu \mathrm{g}$ of $\mathrm{D}$ galacturnoic acid produced. $\mathrm{mg}^{-1}$ protein. $\mathrm{min}^{-1}$ at PM (H1) to $0.52 \mu \mathrm{g}$ of D-galacturnoic acid produced.mg protein.min $^{-1}$ at 15 DAPM (H4).

The variation in polygalactouranase activity in shattering zone of pod wall due to harvesting stages ranged from $0.31 \mu \mathrm{g}$ of D-galacturnoic acid produced. $\mathrm{mg}^{-1}$ protein. $\mathrm{min}^{-1}$ at PM (H1) to $0.36 \mu \mathrm{g}$ of D-galacturnoic acid produced. $\mathrm{mg}^{-1}$ protein. $\min ^{-1}$ at 15 DAPM (H4).

Polygalactouranase activity in both nonshattering and shattering zones of pod wall goes on increasing after PM.

The polygalactouranase activity in nonshattering zone of pod wall ranged from 0.24 $\mu \mathrm{g}$ of D-galacturnoic acid produced.mg ${ }^{-}$ ${ }^{1}$ protein.min ${ }^{-1}$ in variety JS-335 (V3) at PM (H1) to $0.67 \mu \mathrm{g}$ of D-galacturnoic acid produced. $\mathrm{mg}^{-1}$ protein. $\mathrm{min}^{-1}$ in variety KDS837 (V1) and KDS-798 (V2) at 15 DAPM (H4). In pod shattering susceptible varieties KDS-837 (V1) and KDS-798 (V2) polygalactouranase activity went on increasing 
after PM but in pod shattering tolerant JS-335 (V3) and resistant DS-9712 (V4) variety this trend was found fluctuating i.e. lower activity of polygalactouranase up to 10 DAPM (H3) and increased at 15 DAPM $(\mathrm{H} 4)$.

The polygalactouranase activity in shattering zone of pod wall ranged from $0.25 \mu \mathrm{g}$ of $\mathrm{D}$ galacturnoic acid produced. $\mathrm{mg}^{-1}$ protein. $\mathrm{min}^{-1}$ in variety KDS-837 (V1) and KDS-798 (V2) at 15 DAPM (H4) to $0.47 \mu \mathrm{g}$ of $\mathrm{D}$ galacturnoic acid produced.mg ${ }^{-1}$ protein. $\mathrm{min}^{-1}$ in variety JS-335 (V3) and DS-9712 (V4) at 15 DAPM (H4). In pod shattering susceptible varieties KDS-837 (V1) and KDS-798 (V2) polygalactouranase activity found to be decreased after PM (H1) while in pod shattering tolerant JS-335 (V3) and resistant DS-9712 (V4) variety polygalactouranase activity was observed to be increased after PM (H1). Similar, results were also reported by Crookes and Grierson (1983), Smith et al., (1990), Agrawal et al., (2002), Yashodar and Martin (2014) and Pawar (2015).

Table.1 Lignin content in pod wall (per cent)

\begin{tabular}{|c|c|c|c|c|c|c|c|c|c|c|}
\hline$\%$ & 0 & 1 & 2 & 3 & 4 & 5 & 6 & 7 & 8 & 9 \\
\hline Consumed & & & & & & & & & & \\
\hline 10 & 0.911 & 0.913 & 0.915 & 0.918 & 0.920 & 0.923 & 0.925 & 0.927 & 0.929 & 0.931 \\
\hline 20 & 0.934 & 0.936 & 0.938 & 0.941 & 0.943 & 0.945 & 0.947 & 0.949 & 0.952 & 0.954 \\
\hline 30 & 0.958 & 0.960 & 0.962 & 0.964 & 0.966 & 0.968 & 0.970 & 0.973 & 0.975 & 0.977 \\
\hline 40 & 0.979 & 0.981 & 0.983 & 0.985 & 0.987 & 0.989 & 0.992 & 0.994 & 0.996 & 0.998 \\
\hline 50 & 1.000 & 1.002 & 1.004 & 1.006 & 1.009 & 1.011 & 1.013 & 1.015 & 1.017 & 1.019 \\
\hline 70 & 1.022 & 1.024 & 1.026 & 1.028 & 1.030 & 1.033 & 1.035 & 1.037 & 1.040 & 1.042 \\
\hline 70 & 1.044 & & & & & & & & & \\
\hline
\end{tabular}

Using this table as a guide

Fig.1 Partitioning of soybean pod wall in non-shattering zone (Central portion) and shattering zone (Periphery portion)

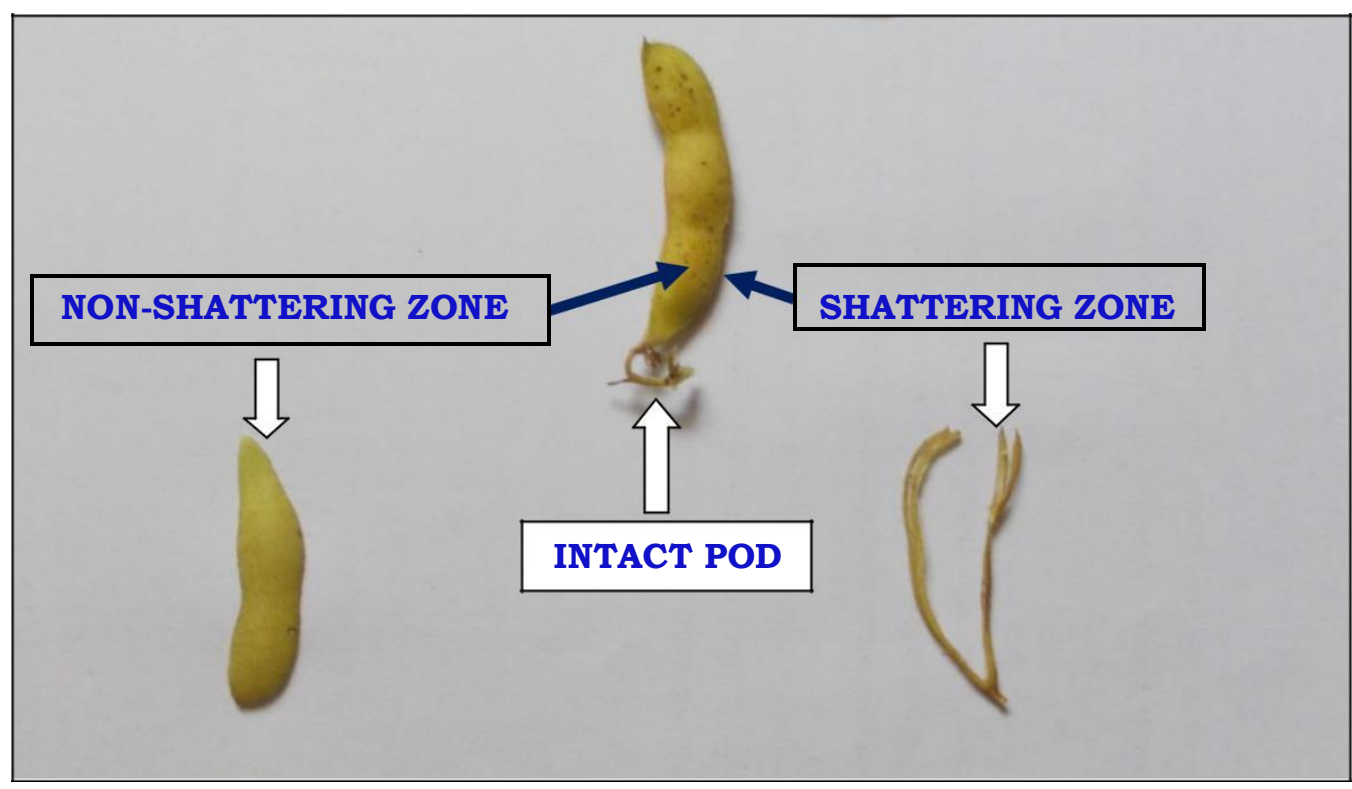


Fig.2 Effect of harvesting stages on lignin content (per cent) in pod wall of soybean varieties
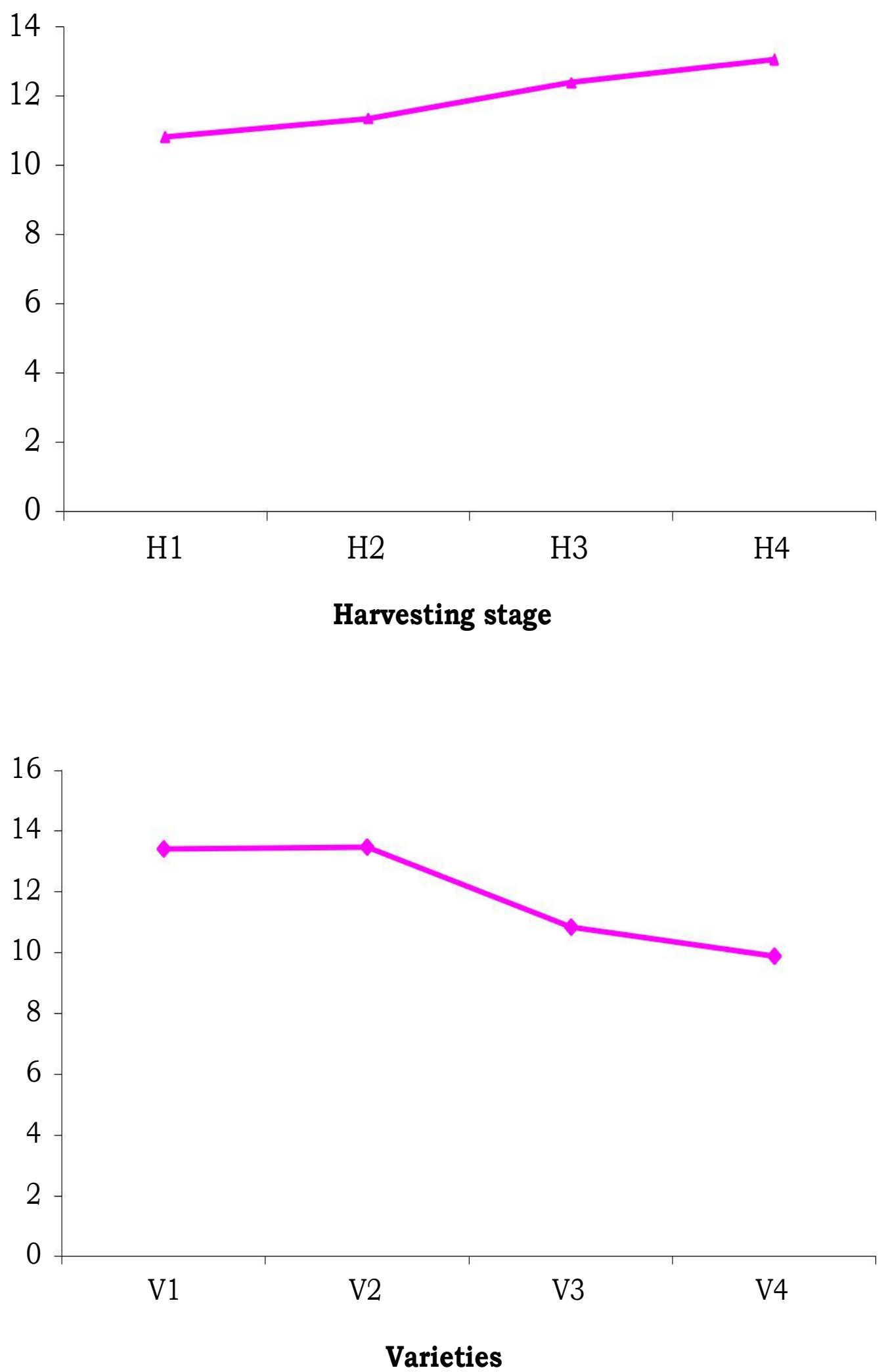
Fig.3 Effect of harvesting stages on polygalactouranase activity in non-shattering zone of pod wall ( $\mu \mathrm{g}$ of D-galacturnoic acid produced.mg-1protein.min-1) of soybean varieties
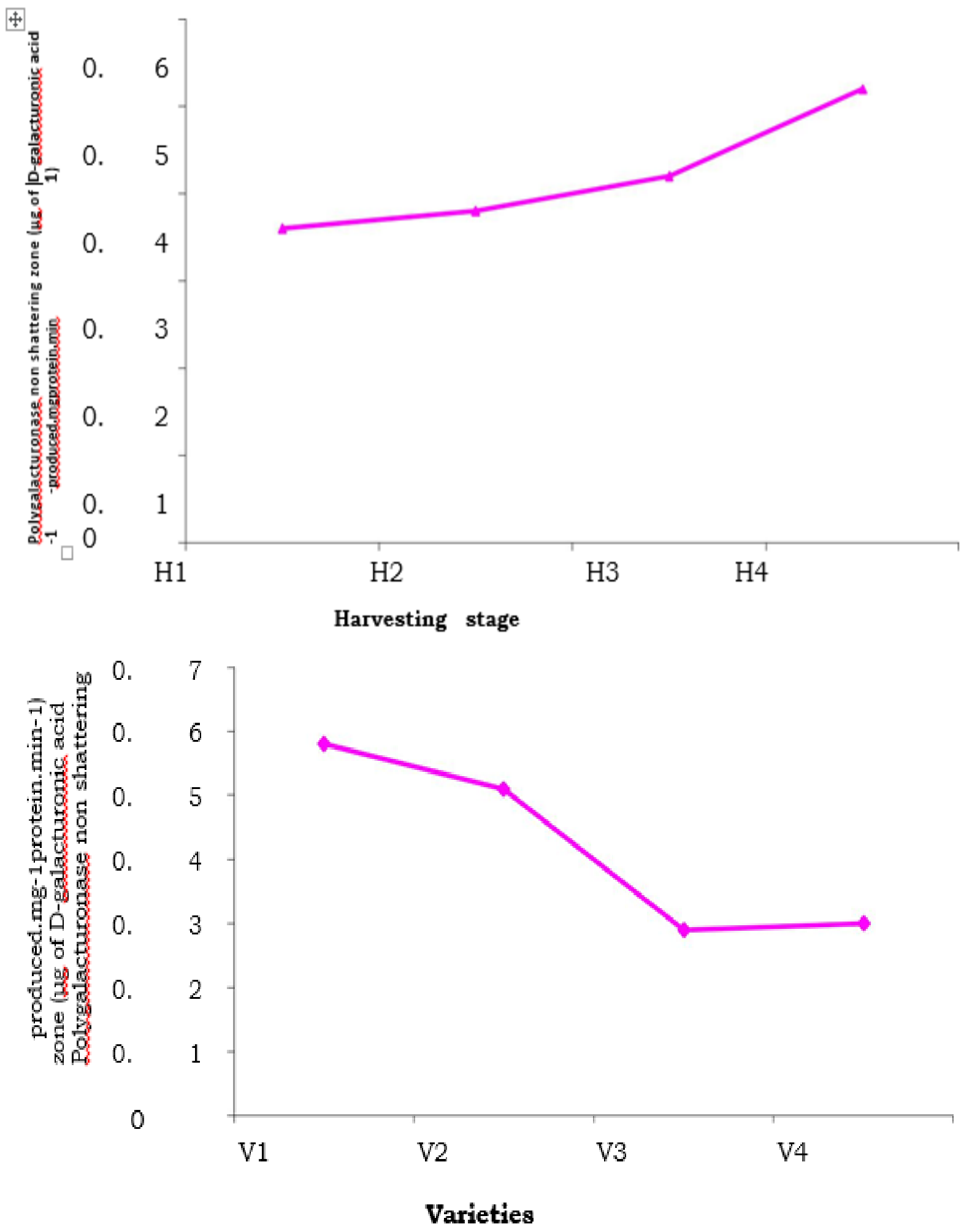
Fig.4 Effect of harvesting stages on polygalactouranase activity in shattering zone of pod wall ( $\mu \mathrm{g}$ of D-galacturnoic acid produced.mg-1protein.min-1) of soybean varieties
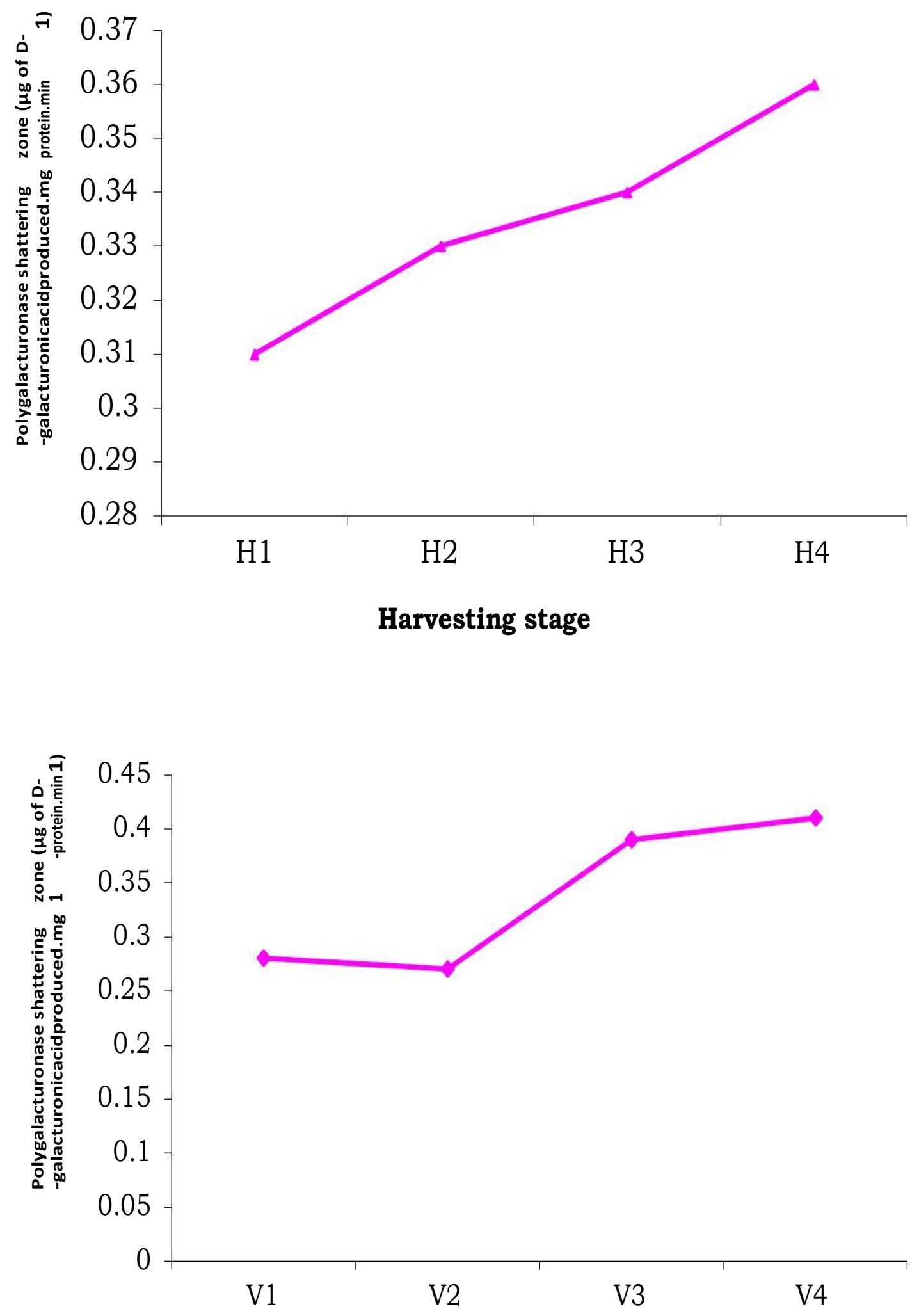
Fig.5 Effect of harvesting stages on cellulase activity in non-shattering zone of pod wall (Dglucose released. $\mathrm{mg}^{-1}$ protein. $\mathrm{min}^{-1}$ ) of soybean varieties
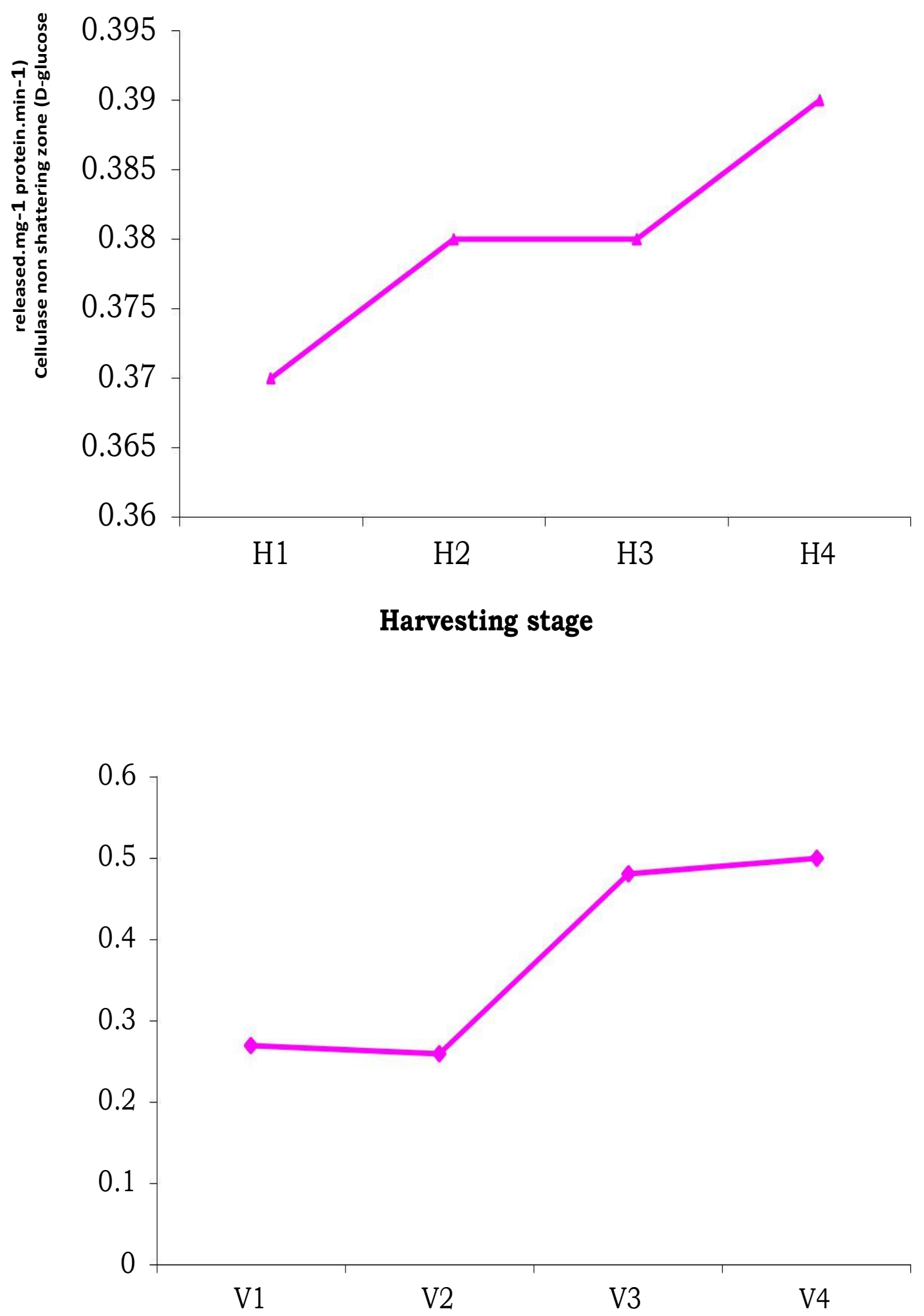
Fig.6 Effect of harvesting stages on cellulase activity in shattering zone of pod wall (D-glucose released. $\mathrm{mg}^{-1}$ protein. $\mathrm{min}^{-1}$ ) of soybean varieties
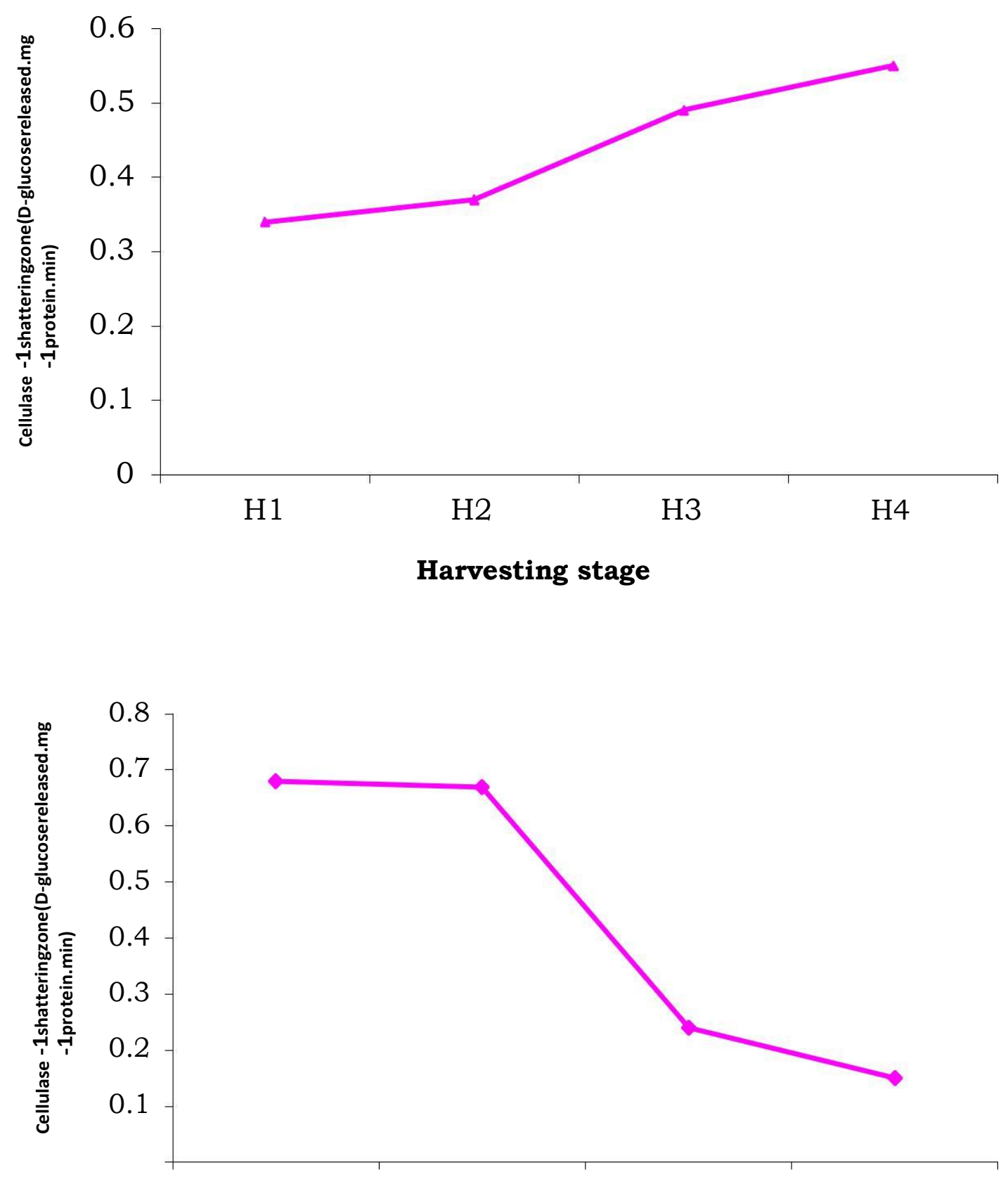

Cellulase activity in non-shattering and shattering zone of pod wall (D-glucose released.mg ${ }^{-1}$ protein. $\mathrm{min}^{-1}$ )

The varietal variation in cellulase activity in non-shattering zone of pod wall ranged from $0.26 \mu \mathrm{g}$ of D-glucose released. $\mathrm{mg}^{-1}$ protein. min $^{-1}$ in variety KDS-798 (V2) to 0.50 $\mu \mathrm{g}$ of D-glucose released. $\mathrm{mg}^{-1}$ protein. $\min ^{-1}$ in variety DS-9712 (V4). It was noticed that in the pod shattering resistant and tolerant varieties had higher cellulase activity in central portion as compared to pod shattering susceptible varieties which exhibited less cellulase activity in central portion i.e. nonshattering zone (Fig. 5). 
The varietal variation in cellulase activity in shattering zone of pod wall ranged from $0.15 \mu \mathrm{g}$ of D-glucose released. $\mathrm{mg}^{-1}$ protein. $\mathrm{min}^{-1}$ in variety DS-9712 (V4) to $0.68 \mu \mathrm{g}$ of D-glucose released. $\mathrm{mg}^{-1}$ protein. $\mathrm{min}^{-1}$ in variety $\mathrm{KDS}-837$ (V2). It was noticed that the pod shattering resistant and tolerant varieties had less cellulase activities in peripheral portion i.e. in shattering zone as compared to pod shattering susceptible varieties which showed higher cellulase activity in shattering zone. It indicates that an increased activity of cellulase in shattering zone of susceptible variety may help in breakdown of the tissues in dehiscence zones of pod wall resulting into pod shattering (Fig. 6).

Harvesting stages showed non-significant difference for cellulase activity in nonshattering zone of pod wall of soybean. However, numerically lowest $0.37 \mu \mathrm{g}$ of $\mathrm{D}$ glucose released. $\mathrm{mg}^{-1}$ protein. $\mathrm{min}^{-1}$ was noticed at PM (H1) to $0.39 \mu \mathrm{g}$ of D-glucose released.mg $\mathrm{m}^{-1}$ protein. $\mathrm{min}^{-1}$ at 15 DAPM $(\mathrm{H} 4)$.

The variation in cellulase activity in shattering zone of pod wall due to harvesting stages ranged from $0.34 \mu \mathrm{g}$ of $\mathrm{D}$-glucose released.mg ${ }^{1}$ protein.min ${ }^{-1}$ at PM $(\mathrm{H} 1)$ to $0.55 \mu \mathrm{g}$ of $\mathrm{D}$ glucose released.mg ${ }^{-1}$ protein. $\mathrm{min}^{-1}$ at 15 DAPM (H4). Cellulase activity in both non-shattering and shattering zones of pod wall was observed to be increased after PM (H1).

The cellulase activity in non-shattering zone of pod wall ranged from $0.24 \mu \mathrm{g}$ of D-glucose released.mg-1 protein. $\mathrm{min}^{-1}$ in variety KDS-798 (V2) at 15 DAPM (H4) to $0.54 \mu \mathrm{g}$ of D-glucose released.mg ${ }^{-1}$ protein. $\mathrm{min}^{-1}$ in variety DS-9712 (V4) at 15 DAPM (H4). In pod shattering susceptible varieties KDS-837 (V1) and KDS798 (V2) cellulase activity was observed to be deceased after PM (H1) while in pod shattering tolerant JS-335 (V3) and resistant DS-9712 (V4) varieties the cellulase activity found to be increased after PM (H1).

The cellulase activity in shattering zone of pod wall ranged from $0.11 \mu \mathrm{g}$ of D-glucose released.mg ${ }^{-1}$ protein. $\mathrm{min}^{-1}$ in variety DS-9712
(H4) at PM (H1) to $0.78 \mu \mathrm{g}$ of D-glucose released.mg ${ }^{-1}$ protein. $\mathrm{min}^{-1}$ in variety KDS-837 (V1) and KDS-798 (V2) at 15 DAPM (H4). In pod shattering susceptible varieties KDS-837 (V1) and KDS-798 (V2) cellulase activity found to be increased after PM (H1) and in pod shattering tolerant JS-335 (V3) and resistant DS-9712 (V4) variety the cellulase activity observed to be increased after PM (H1) but amount of activity was less as compared to in susceptible varieties. Similar, results were also reported by Coupe et al., (1995), Ferrarese et al., (1995), Christiansen et al., (2002), Agrawal et al., (2002) and Pawar (2015). The presence of high levels of cellulase during dehiscence was involved in the process of cell wall degradation. The presence of cellulase the activity of which accumulated in the dehiscence zone was peaked during maturation.

Lignin content in pod wall was more in pod shattering susceptible varieties viz., KDS-837, KDS-798 than tolerant variety viz., JS-335 and resistant variety viz., DS-9712. Polygalactouranase activity in shattering zone of pod wall exhibited higher activities in resistant variety DS-9712 and tolerant variety viz., JS-335 and lower Polygalactouranase activity in shattering zone of susceptible varieties viz., KDS-837 and KDS-798. Cellulase activity in shattering zone of pod wall indicated decreased activities in resistant and tolerant varieties and higher activities in shattering zone of susceptible varieties viz., KDS-837 and KDS798.

\section{Abbreviations}

DAPM-Days after physiological maturity PM-Physiological maturity

H-Harvesting stages

V-Variety

\section{References}

Agrawal, A.P., Basarkar, P.W., Salimath, P.M. and Patil, S.A. 2002. Role of cell walldegrading enzymes in pod shattering process of soybean. Glycine max (L.) Merrill. Curr. Sci., 82(1): 58-61. 
Berger, R.K. and Ried, P.D. 1979. Role of polygalactouranase in bean leaf abscission. Plant Physiol., 63: 1133-1137.

Buscaglia, H.J., Geohring, H.C., Vermeulen, A.M., Fick, G.W. and Lucey, R.F. 1994. Alfalfa yield and quality are affected by soil hydrologic conditions. Agron.J., 86: 535-542.

Chen, H.Q., Gong, Y. and Fang, Z. 1996. The situation and aspect of application for macromolecule (I)-cellulose, lignin and starch. Yunnan Chem.Technol., 11(1): 641.

Christiansen, L.C., Degan, F.D., Ulvskov, P. and Borkhardt, B. 2002. Examination of the dehiscence zone in soybean pods and isolation of a dehiscence-related endopolygalactouranase gene. Plant, Cell and Environment., 25: 479-490.

Coupe, S.A., Bell, S.J. and Roberts, J.A. 1995. Characterization of mRNAs during leaf abscission and their role in cell separation and pathogenic attack. J.Exp.Bot., 46: 3136.

Crookes, P.R. and Grierson, D. 1983. Ultrastructure of tomato fruit ripening and the role of polygalactouranase isoenzymes in cell wall degradation. Plant Physiol., 72: 1088-1093.

Favaron, F., Ovidio, R.D., Porceddu, E. and Alghisi, P. 1994. Purification and molecular characterization of a soybean polygalactouranase inhibiting protein. Planta., 195: 80-87.

Ferrarese, L., Trainotti, L., Moretto, P., Polverinode Laureto, P. and Rascio, N. Casadoro G. 1995. Differential ethyleneinducible expression of cellulase in pepper plants. Plant Mol. Biol., 29: 735747.
Hussain A. M., Huq Emdadul M., Sarder Matiur Rehman and Zakaria Ahmed. 2002. Estimation of lignin in jute by titration method. Pakistan J. Biol. Sci., 5(5): 521522.

Moore, K.J. and Jung, H.G. 2001. Lignin and fiber digestion. J. Range Manage., 54(4): 420-430.

Pawar, D. 2015. Studies on enzyme activities and hormonal levels associated with pod shattering in soybean. M.Sc. (Agri.) Thesis submitted to Dept. of Agril. Biochemistry., M.P.K.V., Rahuri, Maharashtra (India).

Roberts, J.A., Elliott, K.A. and GonzalezCarranza, Z.H. 2002. Abscission, dehiscence and other cell separation processes. Ann. Rev. Plant Biol., 53: 131158.

Romkaew, J., Nagaya, Y., Goto, M., Suzuki, K. and Umezaki, T. 2008. Pod dehiscence in relation to chemical components of pod shell in soybean. Plant Prod. Sci., 11(3): 278-282.

Sadashivam, S. and Manickam. 1992. Biochemical Methods for Agricultural Sciences, Wiley, New Delhi. pp. 124150.

Smith, C.J.S., Watson, C.F., Morris, P.C., Bird, C.R., Seymour, G.B., Gray, J.E., Arnold, C., Tucker, G.A., Schuch, W., Harding, S. and Grierson, D. 1990. Inheritance and effect on ripening of antisense polygalactouranase genes in transgenic tomatoes. Plant Molec. Biol., 14: 369379.

Yashodar, B. and Martin, B. 2014. Plant polygalactouranases involved in cell elongation and separation- The same but different. Plants., 3: 613-623.

\section{How to cite this article:}

Ashvini P. Gaikwad and Bharud, R.W. 2018. Effect of Harvesting Stages and Biochemical Factors on Pod Shattering in Soybean, Glycine max (L.) Merrill. Int.J.Curr.Microbiol.App.Sci. 7(11): 10151026. doi: https://doi.org/10.20546/ijcmas.2018.711.117 